\title{
Milyen legyen a „magyar névpolitika"? Lengyel Zoltán víziója a Magyar névkönyvben (1917)
}

1. Bevezetés. A névpolitika fogalma az utóbbi évek szakirodalmában többször felbukkant, föként a családnév-változtatások és a felvidéki magyarok többnyelvü helységnévtáblái kapcsán. Még nem tisztázott, hogy a kifejezés mikor és hol tünt fel elöször, de amikor LENGYEL ZOLTÁN 1917-ben kiadta Magyar névkönyvét, abban már Magyar névpolitika címmel külön alfejezetet szánt e témának (1917: 209213). Nézetei azért is bírnak jelentőséggel, mert nem nyelvészként vállalkozott a magyar névpolitika elveinek kidolgozására, hanem laikusként: ügyvéd, politikus, parlamenti képviselő és lapszerkesztő volt, valamint a névmagyarosítás aktív pártfogója. ${ }^{1}$ Bár a kötet a szerző szerint , gyakorlati kézikönyv”, melyben a „magyar családi nevek” és „magyar utónevek” gyüjteményét bocsátja az olvasóközönség rendelkezésére (1917: 5,206), a könyv egy tetemes névgyüjteményen jóval túlmutat. A bevezető útmutatásban és a záró fejezetben (1917: 5-47, 199-213) LENGYEL ugyanis összefoglalta gondolatait a magyar nevek alkalmazásáról, a magyar névpolitika mibenlétéről és céljairól, a „magyar névügy” országos megoldásáról (1917: 5). Hangot adott a nézetnek, mely szerint ,....éltudatos, állandó, az egész nemzeti életre kiterjedö magyar névpolitikára van szükség!" (LENGYEL 1917: 209). ${ }^{2}$

A következőkben e névpolitikai elképzelések három pillérének - a státuszés korpusztervezésnek, valamint nyelvi ideológiának - néhány vonatkozása kerül bemutatásra. Bár az átfogó nyelvpolitikai múvek kevés figyelmet szántak a tulajdonneveknek, BOCHMANN szerint a nyelvpolitikának a nevekkel is foglalkoznia kell (1999: 32, 56; 1. még WALKOWIAK 2011: 367), s a névpolitikát utóbb többen a nyelvpolitika részterületeként értelmezték (1. BALÁzS 1997: 484; a szlovákiai magyar kisebbség kapcsán 1. VÖRÖS 2004: 376, 2011: 52; WALKOWIAK 2016: 197). Ez a beágyazódás teszi indokolttá egy tágabb nyelvpolitikai értelmezési keret alkalmazását (Language Policy and Planning, LPP), amely a politika és a tervezés fogalmát nem különíti el mereven egymástól, hanem problémaként tekint rá (1. HORNBERGER 2006: 25, 27-33). Az LPP ide vonatkozó két fö területe kor-

* SZÉPE GYÖRGY emlékének. A vele folytatott beszélgetések a szerző látásmódját több ponton formálták. A szerző köszönetét szeretné kifejezni FARKAS TAMÁSnak a kézirathoz füzött kiegészítő megjegyzéseiért.

${ }^{1}$ LENGYEL ZOLTÁN (1873-1940) 1904-től a Független Magyarország szerkesztője, a Független Párt, majd a Kossuth-párt mellé állt (MARKÓ 2002: 196; KARÁDY-KOZMA 2002: 109). Az Országos Névmagyarosító Társaság megalapítója (erről 1. FARKAS 2002: 159; KARÁDY-KOZMA 2002: 191192). Tevékenységének fókuszában a családnevek magyarosítása állt, nézeteinek ideológiai elemeire MAITZ utalt (2006, 2008a, 2008b, 2009). (Mindehhez 1. még KARÁDY-KOZMA 2002: 109-113.)

${ }^{2}$ A továbbiakban minden, LENGYEL könyvéböl vett idézetben csak eredeti kurzív kiemelések szerepelnek, a magánhangzók hosszúságának jelölése is az eredetihez igazodik. Az idézett névalakok nyelvi adatként a forrástól függetlenül kurziválással vannak jelölve.

Magyar Nyelv 112. 2016: 401-418. DOI: 10.18349/MagyarNyelv.2016.4.401 
pusz- és státusztervezés. Előbbi a nyelvi formákra (1. BOCHMANN 1999: 54-60; COOPER 1989: 122-130), így a nevekre is irányul (WALKOWIAK 2016: 199-200), utóbbi a nyelvek és funkcióik társadalmi és jogi helyzetét, egymáshoz való viszonyát (WALKOWIAK 2016: 197; LABRIE 1999: 18), azaz a domináns többségi és a nemdomináns kisebbségi nyelvű nevek viszonyát is vizsgálja (WALKOWIAK 2016: 200). Az LPP magába foglalja a klasszikus nyelvi tervezési kérdésfelvetéseket (l. COOPER 1989: 29-46), de lehetővé teszi a nyelvi ideológiai háttér figyelembe vételét is. A továbbiakban ez a fogalomrendszer segíti LENGYEL víziójának leírását.

A névpolitika fogalma és kérdésköre ebben az értelmezési keretben nem korlátozható a névhasználatot érintő törvényekre, hanem magába foglalja a nevek tervezését (1. BAUKO 2015: 80, 83), de elsajátításuk tervezését is. De tárgykörébe sorolandók a névpolitikáról vallott nézetek is, hiszen a nyelvpolitikai kutatás tárgykörébe nemcsak a konkrét állami lépések tartoznak, hanem a nyelvpolitikáról való gondolkodás is (SZÉPE 2001: 108). LENGYEL személye így névpolitikai szereplőként tekintendő (vö. BOCHMANN 1999: 36-37). Ha esetében egy laikus nézeteiről van is szó, elképzelései hátterében a fent nevezett három pillér összjátékaként egy névpolitikai gondolkodásmodell rajzolódik ki. Névkönyve e tekintetben azért jelentős, mert ő adott közre elöször magyar keresztnévjegyzéket (FARKAS 2006: 246), amelyet az 1920-as és 1930-as években számos hasonló követett (1. HAJDÚ 2003: 329). Az ilyen egy- vagy többnyelvű névjegyzékek a korpusztervezés megnyilvánulásai (1. WALKOWIAK 2011: 373), ilyenként a tervezési folyamat végeredményét dokumentálják. A névkorpusz ezért következtetni enged a tervező gondolkodásmódjára, a tervezés során érvényesült irányokra és elvekre, de arra is, hogy a tervezőnek milyen elképzelései voltak a magyar nevekről, milyen neveket sorolt e kategóriába. E látásmódról, valamint az egyes neveknek szánt státuszról LENGYEL a magyar névpolitikáról kinyilvánított nézetei is vallanak.

2. A névkonfliktus; a magyar és a kisebbségi nevek státusza és viszonya; a magyar névpolitika területei, feladatai, szereplöi és szervezetei. LENGYEL nézeteinek hátterében egy az ország lakosságának többnyelvüségéből fakadó névkonfliktus állt. A névkonfliktus az újabb névtani kutatásokban már ismert fogalom (1. ŠRAMEK 2008: 11; MAITZ 2008b: 193). A nyelvi konfliktusok egy területe, amelynek ilyenként mind a társadalomban feszülö látens norma-, érdek- és értékellentétek, mind a nyílt konfliktusok a fogalmi körébe tartoznak (a nyelvi konfliktus fogalmára 1. MAITZ 2005: 1-2; RINDLER-SCHJERVE 1997: 16-17). A korban a névkonfliktusok egyik nyílt színtere a névmagyarosítás volt: a magyar többségi társadalom által a nevük miatt stigmatizált vagy diszkreditált nemdomináns kisebbségi nevek viselői állami eljárással egy stigmaszimbólumtól szabadíttatták meg magukat (MAITZ 2005: 177, 2008b: 192-193; egyéb példákra 1. LANSTYÁK 2015: 59-60). A kisebbségi nyelvü nevek viselése LENGYEL szemléletében is konfliktusban állt az ország érdekeivel, az előszó szerint ugyanis a háború hozta „felszinre ezt a mi nagy nyavalyánkat”, az ellenség az országot ,a nem magyarok habarékának” tartja (1917: 9). E „nyavalyát” két példa segítségével mutatta be. Az egyikben arról írt, hogy két katonatisztet idegennek néztek a parlamentben és a sajtóban, idegen hangzású nevük miatt. A másikat abban látta, hogy a katonai 
kitüntetések közlése során esetenként keveslik a magyarok számát, mert a névsorban kevés a magyar név (1917: 9).

Az itt leírt két helyzet fundamentuma az egynyelvü nemzetállam víziója, amelyben a magyar államhoz magyar nyelvet és neveket társítanak, ez a „tiszta nemzetállam" legitimálja a szuverenitást. A kisebbségi nyelvü nevek puszta jelenléte egy olyan államban, amely sem nyelvileg homogén, sem politikailag teljesen független nem volt, s így a nemzetállam képének nem felelt meg, a közéletben lett zavaró tényező, mert többnyelvüként prezentálta az országot a külvilág felé, nyelvi megosztottságot mutatott. LENGYEL nézeteinek hátterében az a feltételezés állt, hogy egy csak magyar neveket viselö társadalom az országot homogén országként mutatná a külvilág felé (vö. WALKOWIAK 2016: 206). Az sem volt véletlen, hogy a két példa a Monarchia haderejének szférájából származott, hiszen a közös hadsereg nyelvhasználata már a késő 1880 -as évektől az egyik fő konfliktusforrás és az elit függetlenségi törekvéseinek szimbóluma volt, mint ahogy az például az 1889. évi véderőtörvény körüli problémákban is megmutatkozott (1. PöLÖSKEI 2001: 70).

A nyelvi konfliktusok megoldásának leírása a nyelvpolitika egyik központi területe (BOCHMANN 1999: 45-47). A konfliktus megoldása LENGYEL szerint ,,minden egyéb elnevezés megmagyarositása" (1917: 212), a nevek nyílt asszimilálása. Gondolkodásmódja az országban beszélt nyelvek hierarchiájára, a magyar nyelv magasabb státuszára épült. A kisebbségi nyelvü neveknek szánt szerepet nem nevesítette. Nézetei inkább csak implikálták, hogy a nekik szánt státusz - a megnevezett cél eléréséig - átmenetileg, implicit módon megtürtek státusza, hiszen a magyar családi nevek felvétele az elfeledésüket, a magyar keresztnevek felvétele a közéletből való kiszorításukat, a magánéletre való korlátozásukat, egyben marginalizálódásukat is jelentette volna. A keresztnevek esetében a kisebbségi nyelvü névváltozatok egy korlátozott névjegyzék kötelezően elöírt alkalmazásával a hivatalos anyakönyvekből többnyire kirekeszthetők, azaz a korpusz- és státusztervezés összjátékaként egyfajta kényszer érvényesíthető. Ezzel szemben családneveknél nem annyira a strukturális eszközök kerültek elötérbe, inkább a propaganda, a meggyőzés és a nyomásgyakorlás (1. MAITZ 2008b: 198-199); a korban ismert névjegyzékek nem rendelkeztek hivatalos státusszal. A kényszert LENGYEL elméletben elutasította, szerinte rendszeres munkával a deklarált célhoz közelebb lehet kerülni (1917: 47). A gyakorlatban az eszköztár a keresztnevek esetében például az állami anyakönyvezésben egyértelmúen kényszer formájában is érvényesült.

A névkönyv az Előszó szerint ,a kormányzat és a társadalom teendőire vonatkozó részletes javaslatokat is tartalmazza” (LENGYEL 1917: 5), így LENGYEL egy névpolitikai cselekvési keretet vázolt fel. Fejtegetéseinek középpontjába egy „Országos (Magyar) Névügyi Tanács” (OMNT) felállítását helyezte, amely központi névpolitikai fórumként az összes föbb feladatot ellátná (vö. BOCHMANN 1999: 39-40). Elsősorban átvenné a Belügyminisztériumtól a névmagyarosítás ügykörét, másodsorban helyneveket terjesztene elő települések alapításánál és névváltoztatásánál, harmadsorban elvégezné a keresztnévjegyzék szerkesztését, az anyakönyvi utasítás módosítását, mivel a minisztérium csak tiltás útján irányíthatja a névadást (1917: 211). A tanács a családnevek esetében döntési, engedélyezési és nyilvántartási feladatokat látott volna el, szervezné és vezetné a vidéki 
előkészítő irodákat, felügyelné a névírást, irányítaná a népszerüsítést, hivatalos névkönyveket adna ki és terjesztené őket. (LENGYEL 1917: 44-45, 212; a felállítandó szervezet nevéhez 1. 1917: 44, 212). A leírtak alapján a tanács a döntési folyamatok mellett a korpusztervezést és a terjesztés irányítását is átvenné, előírásokat hozhatna, azaz állami-kormányzati és civil szerepet ötvözne.

A névpolitika képviselői és fórumai közt LENGYEL mind civil, mind állami szereplőket és szervezeteket megnevezett. Azt kívánta, hogy az OMNT mellett „minden vármegyében, de minden nagyobb városban is tanárokból, egyházi férfiakból, magyar vezető emberekből, tudósokból álló kisebb társaságok alakuljanak" (1917: 212). A vidéki értelmiség feladata lenne, hogy az országban irodákat vezessen, a névmagyarosítás kérdésében tanácsot adjon, propagandát folytasson. Az anyakönyvvezetők, papok kötelessége a „nemzeti sajátosságaink" terjesztése lenne (1917: 203), a névregisztráción jóval túlmutatna. LENGYEL koncepciója így egy centralizált elképzelés, amelyben a regionális szervezetek csak exekutív és mobilizáló funkciót látnának el, a döntés joga a központé.

A felsőbb szük értelmiség - nyelvészek és történészek - kötelessége lenne a magyar nemzeti névanyag tudományos feldolgozása az őskortól a jelenig, annak széles körben való terjesztése (LENGYEL 1917: 206), azaz a szükséges ismeretek felhalmozása, gyüjtése, rendszerezése, rendelkezésre bocsátása. A kimeneti oldal szabályozása, valamint a tudás tartalmáról, milyenségéről leírtak jelzik azt is, hogy a kisebbségi nyelvủ névalakokhoz a nemtudást és nemfejlesztést társította. Ez egybecseng az alkalmazásukra való igény teljes hiányával. A tágabb értelemben vett, müvelt és olvasott értelmiségnek eminens szerep jut a nyelvpolitika kialakításában, a hatalmi struktúrák konzerválásában (BOCHMANN 1999: 36-37). Egyben ugyanarról a társadalmi rétegről van szó, amely a nacionalizmus eszméjének terjesztésében jelentős befolyással bírt. Mint ANDERSON (2006: 74-75) írja, az értelmiség bocsátotta a mítoszokat, az irodalmat, újságokat és az ideológiai megfogalmazást a „nacionalizmus misszionáriusai” rendelkezésére. ANDERSON szerint (uo.) a 19. században olyan szövetségek alakultak egész Közép- és Kelet-Európában, amelyekben az értelmiség és a tudósok a mítoszokat és ideológiai nézeteket szolgáltatták, a kisnemesek a vezető réteget biztosították, $\mathrm{s}$ az üzletemberek a tőkét és a piacot bocsátották rendelkezésre. LENGYEL koncepciójában a magyar nevek terjesztését is ez a csoport, valamint az ún. ideológiai államapparátus tagjai végeznék; az a réteg, amely a nacionalizmus eszméinek terjesztésében is érdekelt volt.

Ezt a koalíciót - a felsőbb értelmiségiek és az andersoni értelemben vett miszszionáriusok tevékenységét - LENGYEL saját személyében is egyesítette, amennyiben a névmagyarosítás pártfogójaként andersoni értelemben vett misszionárius is volt. Bár a korban a nyelvtudomány a névmagyarosítással keveset foglalkozott (FARKAS 2003: 159), a háttérben értelmiségiként olyan nyelvészek is e névpolitikának az aktív közremúködői lettek, mint MELICH JÁNOS, aki LENGYELt tanáccsal látta el (1917: 6), ha munkái nem is szerepeltek a könyv forrásai közt. A nyelvészek körében volt még egy tudós, aki LENGYEL nézeteivel egyetértett: SIMONYI ZSIGMOND. A Magyar Nyelvőr hasábjain a következőképp méltatta LENGYELnek a „névmagyarosítás nagyfontosságú ügyében” szerinte korszakot alkotó könyvét: „A fontos ügy érdekében óhajtjuk, hogy Lengyel Zoltánnak annyi hazafias buzgóság 
sugallta munkája széles körben fölkeltse a megérdemelt figyelmet s emelje a névmagyarosítás ügyét a magyarság terjesztését $\mathrm{s}$ megerősítését célzó nagy nemzeti ügyek közé" (SIMONYI 1917: 204-205; 1. még MAITZ 2005: 118-119). Nyomásgyakorlásra vagy nyelvi kényszerre irányuló kritika hiányzott SIMONYI ismertetéséből, s véleményéből kitünt, hogy a jelenséget nem pusztán tudományos jelenségként közelítette meg, hanem támogatandó társadalmi funkciót társított hozzá.

A névpolitika tárgyköre a személyneveket és a helységneveket is felölelte (LENGYEL 1917: 14). Mi több, LENGYEL a keresztnevek kiválasztását is társadalmi kontroll alá akarta vonni, hogy az ország lakosságának „necsak vezeték, de keresztneve is legyen neki való, a kettö egymással összhangzó és egészen magyar" (1917: 211). Arról, hogy milyen az „egészen magyar” és az idegen személynév, a következőkben lesz szó néhány példa kapcsán.

3. Az „idegen, nemmagyar” és „egészen magyar” nevekről; a névkorpusz kategorizálása és a kategóriák közötti hierarchiák. LENGYEL ZOLTÁNnak a nevek státuszáról alkotott elképzelései egyben kijelölték a korpusztervezés fő irányvonalát. Az ,idegen, nemmagyar” és a „magyar” nevek dichotómiája munkáján nemcsak végigvonult, de a nevek kiválasztásának döntő elve is volt. Ez a dichotómia képezte az első határvonalat, valamint határozta meg egy névnek a közéletben való, javasolt alkalmazását vagy kirekesztését, a nevek hierarchizálását. Bár LENGYEL sehol sem fejtette ki részletesen, mit is ért a „magyar név” fogalma alatt, vagy milyen kritériumok alapján döntötte el egy névről, hogy az magyar-e vagy sem, szemléletmódja a kiválasztott nevek és az azokhoz füzött megjegyzései alapján leírható. ${ }^{3}$ Hiszen a jegyzékbe való felvétel előfeltételezte, hogy egyes neveket előzetesen - valamilyen szempont alapján - magyarnak minősített, másokat pedig idegennek. A jegyzék névkorpuszként az általa magyarnak minősített neveket listázta. Utóbbiak kiválasztása a belefoglalás (inklúzió) és a kirekesztés (exklúzió) segítségével történt, e stratégiák a nemzeti történelem konstruálásában voltak jelen (vö. GYÁNI 2000: 44).

A magyar családnevek alkotják a névkönyv tetemesebb részét (LENGYEL 1917: 50-169), emellett LENGYEL külön A-D) pont alá rendezte a felvételre nem ajánlott, „,sokszor fölvett nevek”, a megtiltandó „,nagy történelmi és irodalmi nevek” és „közjogi, történelmi, egyházi stb. jelentőségủ szavak”, valamint a kivételes esetben engedélyezheto ,idegen szavak és nevek” listáját (1917: 171-179). A magyar családneveket „hasznosíthatóságuk” alapján három csoportba osztotta, s e kategorizálás lett a magyar névkorpusz tervezésének alapelve. A „legjobb” nevek vastagon szedetten, a ,jó” nevek, „közkeletűek”, amelyeknek nincs ,zamatos magyar hangzása", dőlt betüvel, míg a nevek megmaradó többsége kiemelés nélkül szerepelt (1917: 13-14). E csoportok közt LENGYEL nem csupán a jelölés és a jelzők alapján alakított ki vizuális hierarchiát (1. LANSTYÁK 2015: 61), hanem a hozzájuk társított osztályozás, hiányzó egyenértéküség és értékítéletek, valamint

${ }^{3}$ Jelen tanulmánynak nem lehet célja a könyvbe felvett összes név vizsgálata, sokkal inkább csak LENGYEL gondolkodásmódját, a kategóriák közötti átmeneteket és a határsáv létezésének problémáját kívánja bemutatni néhány kiválasztott példán keresztül. Az itt idézetteken kívül a névkönyvben további példák is találhatók. 
a névpolitikai célok alapján is: reményét fejezte ki, hogy a jövőben „kétszer annyi lesz az I. osztályu magyar névből, mint a II. osztályuból és ehhez képest fele annyi a III. osztályuból" (1917: 203). Azt ajánlotta, hogy mindenki az első csoportból válasszon, mert ezáltal egy „magyarosabb” irány (1917: 14-15) juthat érvényre.

A három csoport egymástól való elkülönítése nem nyíltan megfogalmazott kritériumokra épült, hanem homályban maradt. Az ,igazi zamatos” (LENGYEL 1917: 11), magyar eredetű nevek kategóriájáról a szerző leválasztotta a „ha nem is tiszta magyar, de szerintem magyaros hangzású, vagy magyaros végződésü" neveket (1917: 13); utóbbiak kerültek a másik két, kevésbé kívánatos csoportba. Így a 'zamatos hangzás' vagy a 'tiszta magyarság' lehetett az első ilyen elképzelt határvonal a magyar nevek hierarchiájában. Bárminemü katalógus a magyaros végződésekről, a zamatos hangzás kritériumairól vagy a tiszta magyarság jellegzetességeiről természetesen hiányzott. Még kevésbé egyértelmű a II. és a III. csoport szétválasztásának alapja. A III. csoport nevei közt sorolt fel ugyanis olyan neveket, mint a Gothard(i) vagy az Éberhárdi (1917: 88, 78), amelyeket bizonyára nem a magyar etimon alapján vett fel a névkönyvbe, akár idegen névként is értelmezhetök lettek volna. Maga a Gothard név ilyenként a könyvböl ki is maradhatott volna, hiszen felmerül a kérdés, hogy milyen módon felelhetett volna meg a magyaros hangzás, magyaros végződés vagy a magyar helyesírás kritériumának, olyan kritériumoknak, amelyeket LENGYEL nem is definiált. ${ }^{4}$ Bár olyan „idegen eredetü [...] közhasználatú" neveket is felvehetőnek tartott, amelyek szerinte történelmi értékkel bírnak, mint a Fráter, Kontra, Obester/Óbester, ezek egy kiegészítő, D) pont alá sorolt listára kerültek (1917: 13, 179).

Szintén a III. kategóriában szerepeltek a jegyzékben a névmagyarosítás korai szakaszában felvett „,mondva csinált”, ,újmódi nyakatekert, keletkezésük bélyegét magukon hordó nevek" (1917: 8), amelyek nem illeszkedtek a magyar névrendszerbe, idegen névként is lehetett volna őket értelmezni és a névviselő stigmatizálásához is vezethettek. A mai szakirodalom ezeket a mesterséges név fogalmával írja le (1. FARKAS 2003: 152-157). Közülük a jegyzékben szerepel pl. a Rózsafi, a Szépligeti és a Szépszegi vagy a Budapesti (1917: 140, 149, 65). De ilyen mesterséges név ki is maradhatott a jegyzékből, mint a Koszorúfy és a Höskelety, vagy állhatott vastagon szedve az ajánlott ,zamatos, tiszta magyar” nevek közt, mint a Rajna(i) (LENGYEL 1917: 137; az adatok és a motiváció tekintetében 1. FARKAS 2003: 152-153; Rózsafi, 1. FARKAS 2009: 22; Szépligethy, Szépszegi és Budapesti, 1. FARKAS 2003: 152-154).

Bár a szerző a magyar neveket az idegen nevek élesen elkülönített ellenpólusaként jelenítette meg, a III. csoport egy köztes, átmeneti kategóriává formálódott e két pólus közt. Idekerülhettek olyan kiválasztott, idegen eredetü vagy mesterséges nevek, amelyeket nem lehet egyértelmúen idegennek vagy magyarnak nyilvánítani, de a D) lista nevei is ebbe a határsávba tartoztak (1917: 179). A kiválasztás kritériuma,

${ }^{4}$ Felvételének hátterében esetleg az állhatott, hogy a 16. században a székelyek körében használatos volt, azaz a magyar nyelvü lakosság általi használat lehetett a kiválasztott kritérium (vö. BÁRCZI 1958/2001: 127, 1980: 199). Nem ismert, hogy LENGYEL rendelkezett-e ide vonatkozó adatokkal, és az is tisztázatlan, hogy az irodalomjegyzékben szereplő korabeli, személyneveket források alapján közlő műveket milyen módon vette figyelembe a névjegyzék szerkesztésekor. 
mint például a társított történelmi érték, a magyar nyelvközösségben való használat, a magyar morfémák vagy magyar helyesírás függvényében e nevek közül számos mindkét csoportba sorolható lett volna, mint ahogy több más, a könyvbe fel nem vett, de az országban használt kisebbségi nyelvü névalak is. Ez a csoport segített feloldani a magyar és idegen nevek dichotomikus kategóriarendszerét olyan esetekben, amikor a kirekesztéshez a nyelvi valóság nem biztosított egyértelmủ válaszokat.

A III. csoport egyben olyan gyüjtőkategória volt, amelyet önkényes szelekciós prioritások irányítottak, hiszen a példák illusztrálták, hogy az éles határvonal helyett határsáv létezett, amelyben objektíven nehezen vagy nem besorolható nevek is helyet kaptak. A meghúzott határ és a szelekciós eljárások önkényessége LENGYEL elött sem volt titok, hiszen maga is elismerte, hogy „,senki sem lehet abban a helyzetben, hogy minden egyes névre el tudja bírálni, hogy vajjon az bizonyosan magyar-e, vagy sem” (1917: 14). E szubjektivitást mutatja a „szürke, félig magyar, vagy alig magyar" (1917: 11) nevek csoportja, olyan nevekkel, mint a Kovács, Nagy, Szabó, Tóth, Radó (1917: 173-176), amelyeket LENGYEL külön, egy A) jelzetü listában közölt. Az ilyen „elhasznált” (1917: 211) neveket sem ajánlotta felvételre, a magyar neveken belüli hierarchiában a „legkevésbé értékes” minősítést kapták. Hasonlóan szubjektív elv volt a „félmagyar, kényszer-magyar, mesterkélt vagy túlon-túl elhasznált nevek" kizárása, de a ,jó tiszta magyar" (1917: 203) nevek priorizálásának elve is. Az említett névcsoport kirekesztésével LENGYEL e neveknek hasonló státuszt szánt, mint az idegen neveknek.

Az „idegen név” ellenpólusba LENGYEL nemcsak a kisebbségi nyelvü és a mesterséges családnevek egy részét, hanem a „csúf” neveket is sorolta (1917: 46), de nem fejtette ki, hogy pontosan milyen nevek tartoztak a kategóriába. Míg egyes német etimonú neveket felvett a névjegyzékbe, másokat, mint a Braun-t és a Kohn-t idegennek tekintette (1917: 14); ezek ki is maradtak a felsorolásból. Szintén idegen nevek viselői voltak ,a Weiszok, Schwartzok, icsek, vicsek, iczki, viczkiek" (1917: 11), s e besorolást az sem befolyásolta, hogy a nevek kódolásában már magyar grafémák is szerepeltek. A keresztnevek esetében idegennek tekintette a „Barbu (oláh) és a Baruch (zsidó)” nevet is (1917: 205), szerinte a „nem magyarok keresztnevei teljesen nemzetiségi eredetüek” (1917: 203). Ezek az utalások, valamint a keresztnevekhez füzött megjegyzései arra engednek következtetni, hogy a nemzetiségek nevei kerültek a célpontba. A jegyzékbe azokat a neveket integrálta, amelyeket „a nyugattal közösen használunk, és igy nem nemzetiségi vonatkozásuak" (1917: 183). Bár a zsidók nem tartoztak a klasszikus nemzetiségek közé, olyan „beszélő” nevek segítségével, mint a Baruch vagy a Kohn, nyelvpolitikai értelemben a névkönyv egyik leginkább kidolgozott csoportjává váltak. Kiemelésüket a KARÁDY-KOZMA szerzőpáros LENGYEL származásával, azaz a kereszténységhez konvertált zsidó értelmiségi családi háttérrel magyarázta, valamint azzal, hogy a magyarosítást a társadalom zsidó cselekvési mintaként tartotta számon (1. KARÁDY-KOZMA 2002: 109-110). De olyan nevek, mint a Weisz, a Schwartz vagy a Braun mind a magyarországi németek, mind a zsidók körében elterjedtek lehettek (vö. FARKAS 2015: 30-31), annak a két csoportnak a körében tehát, amelyeket az 1870-es évektől felerösödő antiszemitizmus és németellenesség érintett. UNGVÁRY szerint (2002: 731-732) a 19. században csak a városi zsidóknak 
és a falusi sváboknak sikerült a polgárosodás folyamatában részt venni, majd 1919 után általános lett az a nézet, hogy a magyarok sikerének két belső ellensége van: az értelmiségi zsidók és a földeket felvásárló svábok.

A nemzettől ,idegen” képe ellenségképen alapul (GYÁNI 2000: 44), az ellenség evokációja egy kohéziós stratégia (MAITZ 2008b: 202). Az „idegen, nemmagyar” és a ,magyar” nevek dichotómiájában az ,idegen” kimondatlanul is a „saját" jelentéstöbbletét rendeli a „magyar” fogalmához. BUSSE (1997: 32-34) szerint az „idegen” és a „saját” egy olyan diskurzusszemantikai alapfogalompár, amely két kollektívum létét előfeltételezi, így az egységesség képzetét közvetíti a valóság egy olyan szegmenséről, amelyet a valós életben különbözőség ural, s egyedi jellegzetességeket vetít ki e csoportokra. E dichotómia egy világos határvonalat is előfeltételez a két kollektívum között, amely az idegen kizárásának az alapját biztosítja, hiszen az idegenhez automatikusan negatív értékítéletet társít. DIETZ BERING monográfiája (1987) a zsidó-német személynév-változtatások példáján megmutatta, hogy a valóságban a személyneveket sok esetben nem lehet egyértelmủen egy ilyen kategóriarendszer egyetlen pólusához rendelni. LENGYEL e határvonal húzása, a nevek besorolása során egyes neveket a megfelelő kiválasztott kritérium alapján elfogadott, miközben egy másik kritérium alkalmazása esetleg a név kizárásához vezetett volna. A dichotómia segített a nem kívánt nyelvi valóság alárendelésében, eszköze lett a nemmagyar nevekhez rendelt alacsonyabb státusz megvalósításának, az idegen és a magyar nevek hierarchizálásának.

A határvonalak önkényessége a keresztnévjegyzékben is nyomon követhető (LENGYEL 1917: 181-198). LENGYEL felvételre az ,ujonnan forgalomba hozott színtiszta ös magyar“ (1917: 202), „ősmagyar” vagy „őskori” (1917: 15, 203, 199) jelzőkkel leírt neveket ajánlotta. Nem definiálta, mit ért a fogalom alatt, de e kategóriába sorolt olyan, a „nemzeti ujjászületés korszakában” népszerüvé vált neveket, mint az Álmos, Árpád, Attila, Géza, Béla, Dezsö, Farkas, Gyula, Zoltán (1917: 201). ${ }^{5}$ A vastagon szedett, ajánlott nevek közé kerültek a 19. század folyamán felújított vagy a szépirodalomban alkotott nevek, mint a Csilla, Tünde, Etelka és Piroska, illetve a Csaba, a Kálmán és az Etele is. LENGYEL e nevek közül nem mindegyiket ajánlotta, hiszen a Jenö sem került e csoportba, de a Nándor vagy az Aranka sem. Más helyütt közéjük sorolta még a Huba, Tas és a Bátor, Cseke, Erös, Kele, Keve, Makó, Torda neveket is (1917: 199, 201); olyan neveket, amelyek a kor névanyagában nem vagy alig voltak jelen (1. HAJDÚnak a korszakra jellemző névjegyzékét: 2003: 569-570). Az „ősmagyar” nevek fogalmába többségben a valóban használt nevek egy kis részét kitevő „,nemzeti” nevek (LENGYEL 1917: 201), kis részben nem elterjedt nevek tartoztak. A kategóriába sorolást nem az határozta meg, hogy a nevek etimonja magyar, inkább az volt a döntő, hogy a hősi múlt egy epizódját szimbolizálták, így a nemzetépítést szolgálták.

\footnotetext{
${ }^{5}$ Ezeket a szakirodalom a „nemzeti nevek” fogalmával írja le, és a reformkori nemzeti öntudat kifejeződéséhez köti, mert a nemzetre való utalást járulékos információként magukban hordozzák. (A fogalmat részletesen tárgyalja, csoportosítja és a nemzetépítés szerepére utal KECSKÉS 2007: 213-214; 1. még HAJDÚ 2003: 528-529, 532-533 és VÖRÖs 2011: 91, 96. BÁRCZI szerint az Árpád, a Géza és a Zoltán nevek a 19. század elején jelentek meg, 1. 1958/2001: 126; erre a névkönyv megjelenése előtt TOLNAI 1905: 367 utalt.)
} 
A vastagon szedett nevek közt szerepeltek olyan, a kereszténységgel elterjedt, egykor „,idegen” nevek, mint a Teréz vagy az Erzsébet, míg a Katalin és a Margit csak dőlt szedésủ nevekként jelentek meg. De a listára kiemelés nélkül felkerült a Hermann, a Konrád, az Arnold, a Ferdinánd és a Perikles, illetve a női nevek közül a Nandin, a René, a Leona, a Ludmilla vagy a Fedóra, Gertrud, Hermin, Friderika és a Brunhilda. Utóbbiak egyértelmüen ,idegen” etimonra vezethetők vissza, és a korban nem tartoztak az elterjedt nevek közé (vö. HAJDÚ 2003: 569-572). LENGYEL mindent el akart követni, hogy „keresztnevében viselje magán mindenki magyarságának minél erösebb jellegét” (1917: 204), ha nem is tért ki rá, hogy ezek a nevek milyen módon állhattak összhangban a politikai céljaival.

Emellett olyan nevek is szerepeltek a jegyzékében, mint a Sándorka (Alexandra), Ferike (Franciska), Jenőke (Eugenia/Eugénia), Istvánka (Stefánia), Józsika (Josefin/Jozefin), Boldog (Beatrix), Palika (Paula), Gyulácska, Üdvöske, amelyeket LENGYEL szerint bizonyos budapesti körök „uj, csinált, érthetetlen” névként gúnyoltak (1917: 192), azaz részben az új, kitalált nevek közé tartoztak, nem honosodtak meg. Közülük több a 19. sz. elején jelent meg (l. BÁRCZI 1980: 198; 1958/2001: 126). LENGYEL így nemcsak a kisebbségek neveit akarta kizárni, s nem is az országban valósan használt neveket foglalta listába. De a „magyar név” fogalma sem a magyar nyelvben meghonosodott keresztneveket vette számba, hiszen a Stefánia, az Alexandra és az Eugénia már a 19. század második felében használatosak voltak (1. HAJDÚ 2003: 565-568, 571; LENGYEL a zárójelbe tett „idegen nevek” státuszát nem tisztázta). Amint azt az Eugenia/Eugénia, Josefin/ Jozefin (LENGYEL 1917: 194-195, 205) névváltozatok mutatják, e nevek lejegyzése sem volt egységes, mi több, a listában szereplő Josefin sem volt magyaros lejegyzésü, utóbbi inkább Jozefin lett volna. Szintén problémát okozott volna, hogy a Ferike, a Józsika vagy a Sándorka esetében a nöi névalak egybeesett a férfinév kicsinyítő képzős alakjával, ezért nem jelezte volna egyértelmüen a névviselő nemét. Bár LENGYEL többször utalt az anyakönyvi utasításra (1917: 34-35), jegyzéke szükebb volt a hivatalos szabályok által biztosított lehetőségeknél, hiszen azok a magyar nevek bejegyzését alig korlátozták. Ezek a nevek az érvényes utasításnak sem feleltek meg, hiszen a -ka/-ke kicsinyítő képző használata az anyakönyvekben a századforduló óta tiltott volt (1. 80.000/1906. B. M. sz. utasitás... 1906: 1869).

A magyar keresztnevek egyes csoportjaiba való besorolás önkényességét LENGYEL is érzékelte, mert utalt arra, hogy a korban használatos nevek többsége idegen eredetü, „nehéz bennük válogatni” (1917: 183). Annak is tudatában volt, hogy az általa javasolt és a magyarok lakta községekben ténylegesen használt nevek közt nagy volt a távolság, hiszen megjegyezte, hogy vannak olyan „dunántuli és tiszavidéki szinmagyar községek, ahol a köznép leányai is tüntetőleg, kizárólag idegen keresztnevet használnak" (1917: 192). Az sem volt számára ismeretlen, hogy az „ös magyar nevek használata ma még csak egyes családok különlegessége" (1917: 202), nem elterjedt. Az ellentmondások feloldása, rigid határok meghúzása egy névkorpuszban ott, ahol határsávok és átmenetek léteztek, nyelvi ideológiai segítséggel valósulhatott meg, a koncepció harmadik pilléreként. Ennek néhány eleme a következő fejezet tárgya. 
4. Mintha „magyar törzsből származva mindenki magyar nevét örökölte volna", illetve a nyelvi nacionalizmus ideológiájának néhány eleme. A nyelvi nacionalizmus mind a nevek csoportosítását, mind a névpolitikai apparátus és a feladatok körülhatárolását strukturálta. Előbbit MAITZ egy általános, kollektív nyelvi gondolat- és értékrendszerként írta le, melynek legfőbb vonatkoztatási pontja a nemzet, és melyet megalkotói nemzeti érdekekre hivatkozva fejtenek ki és képviselnek (MAITZ 2006: 310-311; 1. még LANSTYÁK 2009: 30-31; FARKASMAITZ 2009: 574; a nyelvi ideológia fogalmára 1. MAITZ 2006: 309-310; további értelmezésekre 1. még LANSTYÁK 2011: 15-16. MAITZ a családnevek tekintetében a névideológia fogalmát is használta, 1. 2008b: 188). ${ }^{6}$ A nemzetre való hivatkozás a könyv LENGYEL névpolitikai nézeteit összefoglaló fejezetén végigvonul, elég csak e tanulmány bevezetésében idézett, az egész nemzeti életre kiterjedő magyar névpolitika céljára gondolni (1917: 5).

A nyelvi nacionalizmusnak a dualizmus időszakában elterjedt elemei közül MAITZ számosat elemzett (1. 2006, 2008a, 2008b, 2009). Közéjük tartozik a többnyelvű névviselésnek a „nyavalya”, azaz a betegség metaforájával való leírása, amely ilyenként orvoslást kíván (MAITZ 2009: 89-90). Ilyen ideológiai elem például a névmagyarosítás ,nagy”, ,,szent” és „nemzeti” üggyé való misztifikálása és glorifikálása (MAITZ 2009: 81-82; példaként 1. LENGYEL 1917: 8, 201) vagy a nemzeti nyelv veszélyeztetettsége (MAITz 2006: 319). Utóbbi a névkönyvben például a magyar nevek ,állandó és rendszeres pusztulásának”, ,nyomoruságos állapotának" képében volt jelen (LENGYEL 1917: 200, 209). Ideológiai elemnek tekinthető a magyar nyelv tökéletessége és felmagasztosítása, vélt felsőbbrendüsége is (MAITZ 2006: 314-315, 2008b: 205), „nemzeti energia” és „,kincsként” való leírása (LENGYEL 1917: 211), valamint az a gondolat is, amely szerint a nemzet és a nyelv egybe kell essen a magyar névvel, az „ezeréves magyar földdel” (MAITZ 2006: 318-319; példaként 1. LENGYEL 1917: 11, 213). Ide sorolja LANSTYÁK (2009: 30-31) a nemzetépítő funkciónak a nemzeti nyelvhez való társítását, de nyelvközi viszonyban a kisebbségi nyelvek visszaszorítására irányuló státusztervezést is. Ez LENGYEL névpolitikai víziójában - minden név magyarosításában - az idegennek tekintett nevek alárendelt státuszában és kirekesztésének szándékában nyilvánult meg. A korpusztervezésben a nyelvi nacionalizmus a domináns kategorizáló elvben mutatkozott meg: az idegen és a magyar dichotómiájában.

LENGYEL célja nemcsak a meglévő magyar nevek terjesztése volt, hanem a közreadott nevek szándéka szerint további új névváltozatok képzését segítik majd (1917: 20), egy új névkorpusz jöhet létre. Az új magyar névváltozatok képzése koncepciójában legitim célnak tűnik (1917: 10, 20, 209), fel is hívta a figyelmet arra, hogy új magyar női neveket kell „teremteni” (1917: 207). Egyben új névhagyományok keletkezését is propagálta, amennyiben e neveket majd a következő, új magyar generáció viseli (1917: 211). Ezt az igényt leginkább az ősmagyar vagy a legjobb magyar nevek terjesztése mutatta. Az „ősmagyar” nevek hagyományként való értelmezését tükrözi, hogy könyvében nézete szerint „,a régiből született,

${ }^{6}$ A nyelvi purizmus a nyelvi nacionalizmus egy válfaja, amely a közösség saját nyelve ellen irányul (LANSTYÁK 2009: 31). Bár a kirekesztés a magyar nevek egy részét is érintette, itt az átfogóbb fogalmi keret használata tünt alkalmasabbnak. 
a hagyományokból táplálkozott, a magyar föld ezeréves talajából kinőtt [...] új Magyarország" van jelen (1917: 11). Ide illeszkedik az a vízió is, amely szerint az idő és a közhasználat „ki fogja válogatni és ki fogja alakítani a magyar keresztnevek olyan mennyiségét, hogy azt [sic] pótolni lesz képes a magyar forgalomban levö összes idegen neveket" (1917: 204).

Ezt az elképzelt új névhagyományt leginkább HoBSBAWM „,kitalált hagyomány" fogalmával lehet leírni. A fogalom olyan, hagyományként bemutatott gyakorlatokat ír le, amelyeket réginek tüntetnek fel, de valójában újak. Egyik jellegzetességük, hogy elfogadott, nem változó, kötött szabályok irányítják öket, míg az egyéb szokások, ünnepek folyamatosan változnak, nem statikusak. De jellemzi őket az is, hogy a hivatkozott korábbi szokásokkal szemben szimbolikus-ideologikus funkciójuk van, és ismétlés által olyan értékeket közvetítenek, amelyek automatikusan kapcsolatot teremtenek a múlttal (HoBSBAWM 1984: 1-14; magyarul 1987: 10-11; a kontinuitásteremtésre utal még MAITZ 2009: 83-84). HOBSBAWM szerint a hagyományok feltalálása a nyelvet, a szókincset is érintette (1984: 7). A kapcsolatteremtés igénye LENGYEL névpolitikai elképzeléseiben is jelen volt: „Mert ezzel az iránnyal az uj magyarok a régi magyarok nevét veszik fel. A történelem folytonosságát kell e téren is helyreállitanunk! Ugy kell magyarositanunk, mintha ezer esztendö óta mind magyarok lennénk és azok maradtunk volna. Úgy kell irányítanunk ezt a dolgot, mintha zavartalan történelmi fejlődés alapján magyar törzsből származva mindenki magyar nevét örökölte volna! Ugy, mint ahogy a tiszta német, a tiszta francia és a tiszta olasz területek lakossága őseitől örökölt német, francia és olasz neveket ismer csak. Ez a teremtett és rekonstruált magyarság olyan legyen, mintha szervesen fejlödött volna!' (1917: 211; más kontextusban idézi KARÁDY-KOZMA 2002: 112; részletét MAITZ 2008b: 204, 2009: 83 is).

A folytonosság képzetének kialakítása olyan esetekben, ahol az már megszakadt vagy csak részben maradt fenn, HoBSBAWM $(1984: 2,12)$ szerint a „kitalált hagyomány" jellegzetessége. Egy korábbi korszakban esetleg részben vagy egy eltérő formában jelen lévő, vélt vagy valós szokásokra való hivatkozás mesterséges kontinuitást teremt, a „régi szokás” legitimál egy megváltozott feltételek közt történő, a korábbihoz képest más jellegü, más társadalmi kontextusban történő, más társadalmi csoportok által gyakorolt jelenkori használatot. Ez a legitimáció a régi szokások legfontosabb funkciója. A folytonosság képzetének megteremtése új társadalmi kontextusban LENGYEL munkájában jól nyomon követhető. Azokat a keresztneveket, amelyeket régiként tüntetett fel, inkább a relatív újdonságuk jellemzett, hiszen itt a 19. század folyamán történeti források alapján rekonstruált, újrakodifikált, újraértelmezett és kitalált névváltozatok hagyományként való etablálását javasolta. LENGYEL a magyar eredetü keresztneveket tartotta a legértékesebbnek, de a középkori, már kihalt vagy csak oklevelekben számos írott változatban fennmaradt, etimológiai értelemben magyar vagy egyéb, esetleg ismeretlen eredetü nevek közül a 19. század első harmadáig, a reformkorig már csak néhány volt használatban. Ebben mutatkozott meg a használatban való törés, amely a kitalált hagyományt jellemzi. Emellett az Árpád-korban már keresztény nevek is használatosak voltak, s az ösiként aposztrofált névváltozatok az 1910-es években választott neveknek is pusztán töredékét képezték. (Az ősmagyar és az ómagyar kor keresztne- 
veinek problémáira 1. HAJDÚ 2003: 347-365.) A nemzetiként megjelenített nevek választását LENGYEL terve gyakorlatilag invariánssá tenné, ha az általa összeállított névlista ennek az elképzelésnek ellent is mondott, hiszen számos más nevet is tartalmazott. A kötöttség vagy változatlanság az egyik olyan jellegzetesség, mely a kitalált hagyományt megkülönbözteti a szokásoktól, utóbbiak HOBSBAWM szerint változékonyak (1987: 2). A névadást - az újszülöttnek kiválasztandó nevet szokásként nem csak a név eredete motiválhatja, hanem más változó faktorok is.

A „régi” egy kiválasztott, HOBSBAWM szerint „erre megfelelö” korra utal (1984: 1). LENGYEL esetében ez a kiválasztott korszak az Árpád-kor és az ún. „ősmagyar” kor, de a két kor részben összemosódik, amikor az Árpád-házi királyok korából fennmaradt ősmagyar nevekről beszél (1917: 15). Az utóbbi időszakát nem határozta meg pontosan, hanem sokkal inkább egy mitikus korra utalt: „Nevében magával hozta és megörizte a magyarság honfoglalása elötti multját, más népekkel való érintkezését, ezeréves hazai történetét és mutatja ma is" (1917: 206). A 18-19. században a kitalált vagy felújított keresztnevek ősiként való átértelmezésével ezeket a neveket gyakorlatilag konstansként, változatlanságukban vetítette vissza erre a honfoglalás előtti mitikus korra, így alapozta meg a „nemzeti nevek" legitimáló funkcióját. SzŰCS JENŐ (1985/1997: 335-336) az ősiség legitimáló erejét ideológiai hídként írta le, amely a nép és az állam origóját a jelen valóságával vagy annak igényével kötötte össze.

Az ősiség elve több tudományterületen jelen volt, a néprajzi kutatások vonatkozásában HOFER (1996) ,az őstörténeti múltba aggály nélkül visszavetített, nemzeti érzéssel átfütött" szemléletként írta le. Ez a gondolkodásmód elterjedt volt a nemzeti történelem konstruálásában (GYÁNI 2000a: 112). LENGYEL a nyelvről és a nevekről alkotott nézeteinek is része volt, hiszen amint azt HAJDÚ (2003: 347-348) megállapította, a személynevek kutatásában az ősmagyar korként megjelölt időszak, a honfoglalás előtti kor névanyagát a későbbi források alapján meg lehet próbálni rekonstruálni, de ez támadható és bizonytalan eredményeket szül. Az adatok és a források hiánya LENGYEL számára is nyilvánvaló volt (1917: 199_ 200), de e nevek elsőbbségét mindettől függetlenül azok vélt vagy valós ősiségével igyekezett legitimálni.

Az ősmagyar vagy magyar nevek segítségével létrehozandó kontinuitást a nemzeti történelem konstruálásában alkalmazott stratégia tette lehetővé: a kirekesztés stratégiája, amelynek segítségével azok a történetek, amelyek nem illenek az egységesség képébe, a nemzeti történelem szempontjából érdektelennek minősülnek és kirekesztődnek (GYÁNI 2000: 44-45). Nem tette ezt máshogy LENGYEL sem: névkönyvében ez a stratégia nemcsak a kisebbségi nyelvü névalakokat érintette, hanem az állam függetlenségében előállt diszkontinuitást vagy megkérdőjelezhető kontinuitást is, mint amilyen Magyarország történetében az oszmán uralom, az ország három részre szakadása vagy a Habsburg Birodalomtól való politikai függés volt (vö. GYÁNI 2000: 33-35). De a migrációt, a betelepítéseket és az etnikai térkép megváltozását a 18-19. században szintén figyelmen kívül hagyta (MAITZ 2008b: 204). Az ilyen érdektelennek minősített történeteket LENGYEL az argumentációból mellőzte. E stratégia segítségével tudta csak az organikus fejlödést, a kontinuitást felmutatni, a magyar nevek segítségével prezentálni. Bár arra 
hivatkozott, hogy ,, a nemzet névanyagában benne van az egész történelem, a múlt, a jelen és a jövő" (1917: 206), e neveknek és történelemnek csak egy választott szegmensét vette figyelembe, az oda nem illő kisebbségi nyelvü névanyagot nem. A kontinuitás megkérdőjelezhetőségének LENGYEL is tudatában volt, mert megemlítette, hogy a nemzeti fejlődés fonalát sokszor átszakították, a magyarságból sok minden kihalt (1917: 208), a „magyarság keresztnevein pedig a faji és társadalmi különbözőség és igy nemzeti széttagoltságunk érzik" (1917: 203).

A kirekesztés stratégiája még legalább egy további vetületben jelen volt a névkönyv koncepciójában: a stratégia részét képezte egy földrajzi értelemben vett kirekesztés. Bár a szerző önképe szerint ,,minden vidék, minden osztály, minden foglalkozási ág" névanyagát gyüjteni kell (LENGYEL 1917: 10), egy magyar névkönyv csak több, dominánsan románok, szerbek, szlovákok által lakott terület névanyagának kirekesztése mellett valósulhatott meg.

A szimbolikus politikai funkció, amely HOBSBAWM szerint a kitalált hagyományt jellemzi, két formában van jelen LENGYEL koncepciójában. Egyrészt a társadalmi különbözőség megváltoztatásának, a „régi magyar nevek” új hagyományként való propagálásának az volt a funkciója a külvilág felé, hogy a magyar egységet és oszthatatlanságot, a homogén nemzetállami jelleget demonstrálják, bizonyítsák és legitimálják. Ez - tekintve a kor kontextusát - az ország feldarabolását volt hivatott megelőzni. Másrészt a kitalált névhagyomány egy befelé irányuló funkcióval is rendelkezett, hiszen a magyar név felvételével a jövő generációit a magyarok közösségébe szimbolikusan belekötötte volna, e néven keresztül az egyén szimbolikusan a nemzet tagjává válna, a szerző szavai szerint a ,, magyar név magyarságukban összekovácsolja a nemzet összes fiait” (1917: 213), és a magyarosítás ,teremthet csak egységes társadalmat" (1917: 11). Ebben a gondolatban mutatkozik meg a magyar nevek terjesztéséhez társított társadalmi funkció, a nemzetépítés, amelyet LANSTYÁK a nyelvi nacionalizmus jellegzetességeként írt le (2009: 30-31), valamint az az elterjedt nézet, mely szerint családnév a nemzeti egység megteremtésének eszköze (FARKAS-MAITZ 2009: 580). A HOBSBAWM által megfogalmazott három hagyománytípus közül (1984: 9) itt a szociális kohéziót teremtő vagy szimbolizáló típus dominál, amely a csoporthoz való tartozást etablálja.

HoBSBAWM szerint a hagyományok kitalálása, bár minden korszakban jelen volt, olyan időszakokban gyakoribb, amikor a társadalomban gyors változások következnek be (1984: 4-5). Ilyen gyors változások lehetősége állt fenn a névkönyv megírásakor, hiszen az az I. világháború idején, annak kontextusában született. Ekkor a Monarchia etnikai-politikai problémái már nem voltak elnyomhatók, fennmaradása kérdésessé vált. Ennek okai közé sorolta RoMSICS (2001: 11) a represszív nemzetiségpolitikát az ország föderatív rendszerủ átszervezése helyett, a nemzetállam fenntartásához való ragaszkodást egy olyan államban, amelyben a nemzetiségeknek saját, függetlenségre törekvő mozgalmuk volt. Egyrészt az ország úgy lépett háborúba, hogy a nemzetiségekkel nem tudott közös vonalat kialakítani, ezért azok politikai lojalitása már a világháború kezdetén kétséges volt. Másrészt a cseh emigráció törekvései, Beneš 1916-os Pusztítsátok el Ausztria-Magyarországot címú pamfletje (ROMSICs 2002: 87, 109-110) és a románok betörése Erdélybe 1916-ban megmutatták, hogy függetlenségi törekvéseik hát- 
terében komoly politikai akarat húzódik. Ez az ellenségkép volt jelen LENGYEL névpolitikai gondolatainak hátterében, amikor arra utalt, hogy köröskörül ,prédára leső ellenségek állnak határainkon”, az ,északi és déli szlávok, az olaszok és oláhok mind a husunkba haraptak” (1917: 212), ,az egész környező világ népmilliói eltiprásunkra szövetkeztek, [...] élet-halálharcot kell vivnunk fennmaradásunkért" (1917: 204). A világ összeesküvésének elmélete a magyarság ellen a könyvben már megjelent, a két világháború közt a fajvédő ideológia múltszemléletének is központi eleme volt (1. GYURGYÁK 2007: 217-227). A nevében egységes nemzet az ellenségek elleni védekezés egy formája is lenne, LENGYEL véleménye szerint egy „névben is egészen magyar Magyarország megszünteti az ellenségek rabló étvágyát”, megmutathatja, hogy „ez az ország nem osztozkodási alap” (1917: 212-213).

5. Zárszó. Egy olyan korban, amelyben a nyelvi emberi jogok fogalma még ismeretlen volt, a névpolitika nem az anyanyelvi névviselés és névhasználat jogát volt hivatott biztosítani, hanem hatalompolitikai megfontolásokat, adott társadalmi struktúrák fenntartását és az uralkodó kultúra hegemóniáját. LENGYEL is a nemzetpolitika szolgálatába állította a névpolitikát: „Az igazi, a valóságos magyar függetlenségi politika egyik alkotó tényezőjéül állítom oda az igazi magyar névpolitikát” (1917: 213). Amikor a „magyar nemzet névanyagát” akarta megállapítani, azt, hogy mennyi ,jó magyar nevünk" van (1917: 9), a kirekesztés stratégiájával a nemzet fogalmát kultúrnemzeti értelemben használta. Egy államnemzeti vonatkoztatású koncepció magába foglalta volna a kisebbségi névváltozatokat is, az ország politikai határain belül létező névként. De szándéka, hogy e névállományt „a magyar nép milliói” (1917: 15) rendelkezésére bocsátja, a belefoglalás stratégiájával a kisebbségi nevet viselőket célozta meg. A háború utáni események megmutatták, hogy egy olyan elképzelés, amely szerint a kisebbségi nyelvü neveket viselők inkább választanák a felkínált új magyar névhagyományt és az önkéntes nyelvi jogfosztottságot, mint a saját nemzetállamuk létrehozását, utópisztikus volt. A trianoni békeszerződés a LENGYEL-féle új névhagyomány képének jelentőségét megváltoztatta és a megcélzott ,idegen” társadalmi csoportokat is leszúkítette.

Kulcsszók: névpolitika, személynevek, névkönyv, Lengyel Zoltán, kitalált hagyomány, idegen és magyar nevek, névmagyarosítás, nyelvi nacionalizmus.

\section{Hivatkozott irodalom}

80.000./1906. B. M. sz. utasitás az állami anyakönyvek vezetéséröl. Magyarországi Rendeletek Tára 40: 1778-1947, 1948-2079.

ANDERSON, BENEDICT 2006. Elképzelt közösségek. Gondolatok a nacionalizmus eredetéröl és elterjedéséröl. Atelier füzetek 8. L’Harmattan Kiadó, Budapest.

BALÁzS GÉZA 1997. Névpolitikai küzdőtér. In: GERGELY B. PIROSKA - HAJdú MiHÁLY szerk., Az V. Magyar Névtudományi Konferencia elöadásai (Miskolc, 1995. augusztus 28-30.) 1-2. A Magyar Nyelvtudományi Társaság Kiadványai 209. Magyar Nyelvtudományi Társaság - Miskolci Egyetem Bölcsészettudományi Intézete, Budapest-Miskolc. 2: 484-491. 
BÁRCZI GÉZA 1980. A magyar nyelv múltja és jelene. Szerk. PAPP LÁSZló. Gondolat, Budapest.

BÁRCZI GÉZA 1958/2001. A magyar szókincs eredete. Tinta, Budapest.

BAUKO JÁNOS 2015. Bevezetés a szocioonomasztikába. Oktatási segédlet. Nyitrai Konstantin Filozófus Egyetem Közép-európai Tanulmányok Kara, Nyitra.

BERING, Dietz 1987. Der Name als Stigma. Antisemitismus im deutschen Alltag 1812-1933. Klett-Cotta, Stuttgart.

Bochmann, KlAus 1999. A nyelvpolitika elmélete, módszerei és elemzése. In: SzÉPE GYÖRGY - DERÉNYI ANDRÁS szerk., Nyelv, hatalom, egyenlöség. Nyelvpolitikai irások. Corvina, Budapest. 25-69.

Busse, DieTrich 1997. Das Eigene und das Fremde. Annotationen zu Funktion und Wirkung einer diskurssemantischen Grundfigur. In: JUNG, MATTHIAS - WENGELER, MARTIN - BÖKE, KARIN Hrsg., Die Sprache des Migrationsdiskurses. Das Reden über „,Ausländer” in Medien, Politik und Alltag. Westdeutscher Verlag, Opladen. 17-35.

COOPER, ROBERT L. 1989. Language planning and social change. Cambridge University Press, Cambridge.

FARKAS TAMÁS 2002. Nyelvmüvelés és családnév-változtatás. In: BALÁZS GÉZA - A. JÁSzÓ ANNA - KOLTÓI ÁDÁM szerk., Éltető anyanyelvünk. Mai nyelvmüvelésünk elmélete és gyakorlata. Írások Grétsy László 70. születésnapjára. Tinta, Budapest. 159-163.

FARKAS TAMÁS 2003. A magyar családnévanyag két nagy típusáról. Magyar Nyelv 99: $144-163$.

FARKAS TAMÁS 2006. Keresztnévkönyvek - keresztnévtárak - keresztnévszótárak Magyarországon. In: MÁRTONFI ATTILA - PAPP KORNÉLIA - SLÍZ MARIANN szerk., 101 irás Pusztai Ferenc tiszteletére. Argumentum, Budapest. 246-252.

FARKAS TAMÁS 2009. Szempontok, irányok, feladatok és lehetőségek a családnév-változtatások vizsgálatában. In: FARKAS TAMÁS - KOZMA ISTVÁN szerk., A családnévváltoztatások történetei idöben, térben, társadalomban. Gondolat - Magyar Nyelvtudományi Társaság, Budapest. 11-27.

FARKAS TAMÁS 2015. Changing names and abolishing the difference. Personal names as ethnic symbols, characteristics of surname changes and the magyarization of surnames in Hungary. Létünk 45/3: 27-39.

FARKAS TAMÁS - MAITZ PÉTER 2009. Nyelvi nacionalizmus és német családnevek a 19. századi Magyarországon. A névmagyarosítások nyelvi-ideológiai hátteréről. Századok 143: 565-592.

GYÁNI GÁBOR 2000. Fin de siécle-történetírás. In: GYÁNI GÁBOR, Emlékezés, emlékezet és a történelem elbeszélése. Napvilág, Budapest. 31-47.

GYÁNI GÁBOR 2000a. Történetírás: a nemzeti emlékezet tudománya? In: GYÁNI GÁBOR, Emlékezés, emlékezet és a történelem elbeszélése. Napvilág, Budapest. 95-127.

GYURGYÁK JÁNOS 2007. Ezzé lett magyar hazátok. A magyar nemzeteszme és nacionalizmus története. Osiris, Budapest.

Hajdú Mihály 2003. Általános és magyar névtan. Személynevek. Osiris, Budapest.

HoBSBAWM, ERIC 1984. Introduction. Inventing Traditions In: HOBSBAWM, ERIC - RANGER, TERENCE eds., The Invention of Tradition. Cambridge University Press, Cambridge. 1-14. http://dx.doi.org/10.1017/CBO9781107295636.001 
HoBSBAWM, ERIC 1987. Tömeges hagyomány-termelés: Európa 1870-1914. In: HofER TAMÁS - NiEDERMÜlLER PÉTER szerk., Hagyomány és hagyományalkotás. MTA, Budapest. 127-197.

HOFER TAMÁS 1996. Östörténet a néprajz látószögében. BUKSZ 8/3: 301-304.

Hornberger, NANCY H. 2006. Frameworks and Models in Laguage Policy and Planning. In: Ricento, Thomas ed., An Introduction to Language Policy. Theory and Method. Blackwell, Malden. 24-41.

KARÁDY VIKTOR - KOZMA ISTVÁN 2002. Név és nemzet. Családnév-változtatás, névpolitika és nemzetiségi erőviszonyok Magyarországon a feudalizmustól a kommunizmusig. Osiris, Budapest.

KECSKÉS JUDIT 2007. Nemzeti nevek és a nemzeti öntudatra ébredés nevei. In: HoFfMANN ISTVÁN - JUHÁSz DEZSŐ szerk., Nyelvi identitás és a nyelv dimenziói. Nemzetközi Magyarságtudományi Társaság, Debrecen-Budapest. 209-216.

LABRIE, NORMAND 1999. Nyelvpolitika. In: SzÉPE GYÖRGY - DERÉNYI ANDRÁs szerk., Nyelv, hatalom, egyenlöség. Nyelvpolitikai írások. Corvina, Budapest. 15-25.

LANSTYÁK ISTVÁN 2009. Nyelvi ideológiák és filozófiák. Fórum. Társadalomtudományi Szemle 2009/1: 28-44.

LANSTYÁK ISTVÁN 2011. A nyelvi ideológiák néhány általános kérdéséről. In: MISAD KATALIN - CSEHY ZOLTÁN szerk., Nova Posoniensia. Szenczi Molnár Albert EgyesületKalligram Kiadó, Pozsony. 13-57.

LANSTYÁK ISTVÁN 2015. Nyelvalakítás - névalakítás. A tulajdonnevekkel kapcsolatos nyelvi problémák kezelése a nyelvmenedzselés-elmélet keretében. In: VÖRÖS FERENC - MISAD KATALIN szerk., A nyelvföldrajztól a névföldrajzig $V$. Interetnikus kapcsolatok. A 2014. november 20-21-i pozsonyi névföldrajzi tanácskozás előadásai. Szenczi Molnár Albert Egyesület, Pozsony. 43-75.

LENGYEL ZOLTÁN 1917. Magyar névkönyv. Nap nyomda, Budapest.

MARKÓ LÁSZLÓ szerk. 2002. Új magyar életrajzi lexikon 4. Magyar Könyvklub, Budapest.

MAITZ PÉTER 2005. Sozialpsychologie des Sprachverhaltens. Der deutsch-ungarische Sprachkonflikt in der Habsburgermonarchie. Niemeyer, Tübingen. http://dx.doi.org/[-] $10.1515 / 9783110913743$

MAITZ PÉTER 2006. A nyelvi nacionalizmus a dualizmus kori Magyarországon. Egy nyelvi ideológia elemei. Magyar Nyelv 102/3: 307-322.

MAITZ PÉTER 2008a. A,,szent ügy”. A dualizmuskori névmagyarosítási propaganda nyelvészeti elemzése. Névtani Értesítö 30: 7-33.

MAITZ PÉTER 2008b. Der Familienname als Ausschluss- und Machtin Eine kritisch-diskursanalytische Fallstudie. In: Eller, NiCOLE Hrsg., Namen und ihr Konfliktpotential im europäischen Kontext. Regensburger Symposium, 11. bis 13. April 2007. Edition Vulpes, Regensburg. 11-16.

MAITZ PÉTER 2009. Névmagyarosítás és névideológia a dualizmus kori Magyarországon. In: FARKAS TAMÁS - KOZMA ISTVÁN szerk., A családnév-változtatások történetei időben, térben, társadalomban. Gondolat - Magyar Nyelvtudományi Társaság, Budapest. 77-93.

PÖLÖSKEI FERENC 2001. A magyar parlamentarizmus a századfordulón. Politikusok és intézmények. MTA, Budapest. 
RINDLER-SCHJERVE, ROSITA 1997. Sprachpolitik aus der Sicht einer Sprachwissenschaftlerin. In: RINALDI, UMBERTO - RINDLER-SCHJERVE, RositA - METZELIN, MICHAEL Hrsg., Lingua e politica. La politica linguistica della duplice monarchia e la sua attualita. / Sprache und Politik. Die Sprachpolitik der Donaumonarchie und ihre Aktualität. Istituto Italiano di Cultura (Wien), Wien. 13-23.

ROMSICS IGNÁC 2001. Nemzet és állam. Rubicon 2001/89: 4-15.

ROMSICS IGNÁC 2002. Magyarország története a XX. században. Osiris, Budapest.

SimONYI ZSIGMOND 1917. Magyar név. Magyar Nyelvőr 46: 200-205.

ŠRAMEK, RUDOLF 2008. Typologisierendes zu Namenkonflikten. In: ELLER, NiCOLE Hrsg., Namen und ihr Konfliktpotential im europäischen Kontext. Regensburger Symposium, 11. bis 13. April 2007. Edition Vulpes, Regensburg. 11-16.

SzÉPE GYÖRGY 2001. Magyarország nyelvpolitikája és a kutatás. In: SzÉPE GYÖRGY, Nyelvpolitika. Múlt és jövő. Iskolakultúra, Pécs. 107-120.

SzÜCS JENŐ 1985/1997. Történeti „eredet”-kérdések és nemzeti tudat. In: SzŰCS JENÖ, A magyar nemzeti tudat kialakulása. Szerk. ZIMONYI IsTVÁN. Osiris, Budapest. 334-369.

TOLNAI VILMOS 1905. A magyar keresztnevekről. Magyar Nyelv 1: 367-368.

UNGVÁRY KRISZTIÁN 2002. Antiszemitizmus és németellenesség - a kétfrontos harc. In: KARSAI LÁSZLÓ - MOLNÁR JUDIT szerk., Küzdelem az igazságért. Tanulmányok Randolph L. Braham 80. születésnapjára. MAZSIHISZ, Budapest. 731-750.

VÖRÖS FERENC 2004. Névpolitika a Felvidéken. In: BALÁZS GÉZA szerk., A magyar nyelvi kultúra jelene és jövője 1-2. MTA, Budapest. 1: 367-381.

VÖRÖS FERENC 2011. Nyelvek és kultúrák vonzásában. I. Személynevek a magyar nyelvterület északi pereméröl. Kalligram, Pozsony.

Walkowiak, Justyna B. 2011. Minority Language Policy regarding Personal Names. An Overview. ESUKA - JEFUL 2/1: 367-382.

Walkowiak, Justyna 2016. Personal Names in Language Policy and Planning: Who Plans What Names, for Whom and How? In: PUZEY, GuY - KostAnsKi, LAURA eds., Names and Naming. People, Places, Perceptions and Power. Multilingual Matters, Bristol-Buffalo-Toronto. 197-212.

\section{What should a "Hungarian naming policy" be like?}

\section{Zoltán Lengyel's vision in his Hungarian Book of Names (1917)}

When Zoltán Lengyel published his collection of Hungarian family names and given names in 1917, he pointed out that a Hungarian naming policy would be necessary. The aim of this paper is to analyse three pillars of his ideas about such a naming policy. The first part surveys status policy: naming conflicts, a suggested solution, and agents of naming policies. The second part scrutinizes corpus planning: the dichotomy of foreign and Hungarian names was the basis of including certain selected foreign names in the book of names and discarding others. The author argues that although Lengyel made a clean-cut distinction between foreign and Hungarian names, his corpus of names exhibited a border area rather than a sharp dividing line. That border area included names that could have been attributed to either pole on the basis of the criteria given; their classification was arbitrary in many cases. In classifying Hungarian names, Lengyel attached value judgements to the groups in terms of 
utility; he emphasized the priority of ancient Hungarian names as opposed to "ugly" or "worn-out" ones. Finally, the paper discusses linguistic nationalism and proposes that Lengyel's ideas show parallels to the phenomenon of "invented tradition" as described by Eric Hobsbawm.

Keywords: naming policy, personal names, name book, Zoltán Lengyel, invented tradition, foreign vs. Hungarian names, Hungarianisation of names, linguistic nationalism.

BERnADETTE GeBHARDT Pécsi Tudományegyetem 